Article

\title{
Corporate Social Responsibility Practices in the U.S.: Using Reverse Supply Chain Network Design and Optimization Considering Carbon Cost
}

\author{
Bandar Alkhayyal \\ Department of Engineering Management, College of Engineering, Prince Sultan University, Riyadh 12435, \\ Saudi Arabia; balkhayyal@psu.edu.sa
}

Received: 24 January 2019; Accepted: 3 April 2019; Published: 9 April 2019

check for updates

\begin{abstract}
A research model using the market price for greenhouse gas (GHG) emissions illustrates how the policies, and economic and environment implications of the carbon price can be formulated using a deterministic equilibrium model. However, with increasing carbon costs, the optimal reverse supply chain (RSC) system is being required to adapt and has undergone many distinct shifts in character as it seeks out new configurations through which costs may be effectively managed and minimized. The model was studied comprehensively in terms of quantitative performance using orthogonal arrays. The results were compared to top-down estimates produced through economic input-output life cycle assessment (EIO-LCA) models, providing a basis to contrast remanufacturing GHG emission quantities with those realized through original equipment manufacturing operations. Introducing a carbon cost of $\$ 40 / \mathrm{t} \mathrm{CO} 2 \mathrm{e}$ increased modeled remanufacturing costs by $2.7 \%$, but also increased original equipment costs by $2.3 \%$. The research presented in this study puts forward the theoretical modeling of optimal RSC systems and provides an empirical case study concerning remanufactured appliances, an area of current industrial literature in which there is a dearth of study.
\end{abstract}

Keywords: reverse supply chains; circular economy; sustainability; governance; business; society; policy

\section{Introduction}

The circular economy concept was developed as an alternative to the prevailing production paradigm of treating the environment as a waste reservoir, and was first raised four decades ago in a report submitted to the European Commission [1]. A circular economy (CE) is described as turning end-of-life goods into resources for others and minimizing waste, applying the concept of closing loops in industrial ecosystems. Frosch and Gallopoulos published an important work in the area of industrial ecology in 1989, inspiring a positive change from traditional open loop industrial activities systems to a model of industrial activities with a higher level of integration —an industrial ecosystem. This system has been described as one in which "the consumption of energy and material is optimized, waste generation is minimized and the effluents of one process ( ... ) serve as the raw material for another process" [2]. This could slowly replace the economic logic of production by being more efficient through reusing, recycling, and remanufacturing, leading to economic growth. In a study on CE undertaken by a number of European nations, it was found that greenhouse gas emissions would be reduced by each nation up to $70 \%$, and at the same time the workforce would increase by about $4 \%$ [3]. Recently, in Paris, the 21st Conference of the Parties to the United Nations Framework Convention on Climate Change (UNFCCC) [4], reached a new global agreement through which the agreed parties voiced their commitment to achieving the goal of generating zero net GHG emissions by the latter part of the 21st century.

The concept of the reverse supply chain (RSC) is a growing initiative that may take a key position in the global supply chain for parties seeking to identify environmentally responsible strategies to deploy 
for their end-of-life (EOL) products [5-7]. For years, the quantity of discarded consumer products has been rising, and as a result there has been increased legislative action in countries that use original equipment manufacturers (OEM) for them to be held accountable for their end-of-life processing of products under extended producer responsibility (EPR) policies [8,9]. Certainly, consumer awareness of environmental issues has a marked effect on the supply chain, because consumers buy refurbished units and value environmental information on suppliers and retailers. RSC production benefits, in economic and environmental terms, are associated with costs and emissions in the course of collecting, transporting, recovering facilities, disassembling, recycling, remanufacturing and discarding components that are not recoverable [10].

The definition of remanufacturing is "a process that brings a used product back to a new state through reuse, refurbishment and replacement of its components" [11]. It is a sequence that involves the reprocessing of used products by disassembling, cleaning, inspecting, sorting, repairing, or replacing of components (if applicable) and their eventual reassembly as a remanufactured product. Restoration can generate items that are in as new, or even better, condition than those items considered brand new, and returns a product to the market with not only the same functionality, but an extended life cycle. The recycling of end-of-life products that have been recovered, and their parts, by way of a remanufacturing scheme will ultimately decrease the industrial and disposal expenses associated with material-intensive and heavy equipment and machinery [12-15]. This remanufacturing system relies on a reverse supply chain (RSC) - a set of logistical operations and actors to recover used products and deliver them to OEMs and third-party manufacturers. According to the recently published United States International Trade Commission (USITC) report, the market in the U.S. for remanufactured goods rose by $15 \%$ from $\$ 36.0$ billion in 2009 to $\$ 41.5$ billion in 2011. During the same time, the value of U.S. remanufactured production increased by $15 \%$ to at least $\$ 43.0$ billion; hence, this would have created 180,000 full-time jobs in the U.S. and exports totaling $\$ 11.7$ billion of remanufactured goods [16]. In another estimate, the U.S. remanufacturing industry is a $\$ 50$ billion industry at minimum, distributed throughout some 73,000 firms, with direct employment of 480,000 [17].

In 2015, the U.S. alone returned products worth $\$ 261$ billion, out of a total of $\$ 3.3$ trillion sold. This makes a vast returned products market, with sales over $\$ 486$ billion in 2014 [18]. Moreover, the sales for the secondary market rose by $31 \%$ from 2010 to 2014, and due to growth of e-commerce this rise is set to be much higher. With online purchases, returned goods are increasing due to the fact that customers buy without seeing them. By 2020, the U.S. e-commerce sales are anticipated to be $50 \%$ greater than in 2015, offering enormous opportunity [18]. The secondary market has both an environmental benefit resulting from extended product life, and a social benefit by increasing buyer and seller access.

In general, remanufacturing has been found to be the most environmentally friendly option for end-of-life products, in terms of both avoiding waste and substituting for primary materials and upgrading product performance, which saves energy (and associated emissions) during product use. To determine the validity of the hypothesis that product remanufacture saves energy, Gutowski et al. [17] studied eight different product categories in the U.S. that have significant remanufacturing potential: appliances, clothing, computers, electric motors, engines, tires, and toner cartridges.

Currently, there are international, national, and corporate policies intended to reduce pollution in a flexible and economical manner [19]. This paper emphasizes the social cost of carbon (SCC) emitting a metric ton of carbon dioxide. The SCC was valued by the U.S. Environmental Protection Agency (EPA), in concert with additional federal agencies, to estimate climate benefits against the costs of meeting targets. The purpose of this paper is to present a comparison of economic and environmental impacts of remanufactured air conditioners in a model for a reverse supply chain, and to test the effect of emissions pricing on optimal configurations of a RSC. Air conditioners (A/Cs) were chosen due to their large and growing market, and as they are a target of remanufacturing efforts due to the presence of refrigerants with mandated handling rules. 
This study solves a case study with the support of an operations model, and considers the following research questions:

- What is the social cost of carbon (SCC) effect on unit price?

- How is carbon priced to achieve maximum emissions reduction while ensuring that the remanufacturing profits are not overly affected?

- What is the cost-effectiveness over a range of carbon prices?

- Is it possible reduce emissions without increasing cost, by using only operational adjustments?

- What is the best carbon price to maximum emissions reduction and maximize profit?

- What is the most efficient method for recovery of used products?

- What network best reflects the organization's environmental and carbon market strategy?

- What are the flow networks for the returned products through the reverse logistics (RL) network?

Herein, a mixed-integer linear programming (MILP) optimization platform is used for reverse supply chains that have a full estimation of emissions, to identify the ideal movement of products within a number of remanufacturing facilities (thereby maximizing net profits while minimizing CO2 emissions) by investigating the cost factors and total $\mathrm{CO} 2 \mathrm{e}$ from actual remanufacturing sites in the Boston area.

Having presented the introduction, the remainder of this paper comprises: Section 2, presents a literature review on the circular economy, reverse supply chains, and greenhouse gas emissions; Section 3, in which the methodology used in this study is presented; Sections 4 and 5 contain a thorough exploration of nomenclature and problem formulation; Section 6 explains the case study and results; Section 7 details results of the experimental studies; finally, in Section 8, conclusory remarks are presented.

\section{Literature Review}

\subsection{Present State of Research on the Circular Economy and Reverse Supply Chains for Remanufacturing}

A circular economy encourages the use of remanufacturing rather than alternative waste management approaches such as reusing, recycling, disposal, and recovery. A critical and thorough review of extant research on remanufactured products using reverse logistics was conducted by Peters [20]. Recent research by Derigent and Thomas [21] concerned product and material recycling in the context of a circular economy, including a review of the existing literature and highlighting potential research directions. Govindan and Soleimani [22] conducted an exhaustive review of research on reverse supply chain issues, finding that often an effective reverse supply chain can bring about a reduction in the total costs associated with reverse logistics operations, in addition to the demand for new raw materials that enter the supply chain. Guide et al.'s [23] survey found that, in order to decrease the unknown causes of return quantity and quality, a product acquisition management strategy that is market-driven to the collection of used products has been adopted by a number of U.S. remanufacturing firms.

Examples abound, such as the Green Citizen Company, which purchases used Apple products, including desktops, laptops, iPads, and iPhones. EcoATM is the first automated eWaste recycling on the planet, and provides the user with instant cash when responsibly recycling old electronics, including MP3 players, cell phones, and tablets. By December 2014, ecoATM had an estimated 1890 kiosks situated in a number of large retailers and shopping malls across the country [24]. Kodak was able to control the number of used cameras that were returned by offering incentives, including cash [25]. Fleischmann et al. [26], found that the remanufacturing costs of IBM were $80 \%$ lower than the cost of purchasing new parts. Likewise, for the Xerox Corporation, $40 \%-65 \%$ of their manufacturing costs can be saved by applying their remanufacturing program to the materials and parts taken from products that are returned [27]. The Dell computer company dynamically adjusts prices based on inventory levels of products to improve supply chain efficiency [28]. 
In environmental terms, remanufactured products are highly sustainable and encourage both energy and resource saving; the procedures involved also create jobs for skilled workers [29] Ultimately, product remanufacturing process decisions must be integrated during the earlier stages of the product life cycle $[30,31]$ to guarantee these kinds of successful outcomes.

An effective RSC can help enterprises better utilize their resources and maintain a more sustainable balance between the economy and the environment [32]. RSC practices present further value for 'greening' the entirety of the supply chain through the reintroduction of used and end-of-life products into the system of production [33]. RSC operations are widely considered a central component of a circular economy [34]. Alqahtani and Gupta [35] proposed two multi-criteria optimization models for product delivery over many periods within the context of a reverse supply chain environment. The first model is solved through the utilization of mixed-integer linear programming (MILP), with the second model being solved through the use of linear physical programming (LPP). The models proposed provide the optimal transport quantities for the reverse supply chain of remanufactured products spread over N-periods. Boustani et al. [36], studied the entire life cycle for manufacturing and remanufacturing, and measured the energy consumption for different appliances, such as, dishwashers, washing machines, and refrigerators. They found that remanufacturing saves $14 \%$ for dishwashers, $32 \%$ for refrigerators, and $44 \%$ for washing machines. Sutherland et al. [37] established a cost model to investigate the challenges of selecting the size of remanufacturing facility. The model developed considered such aspects as transportation and production, as well as costs associated with inventory, and described the effects of economies of scale.

An exhaustive review of literature was undertaken by Mexiell and Gargeya [38] on the economic concerns linked to the design of supply chains, while Seuring and Muller [39] and Srivastava [40], published an extensive literature review of articles considering sustainable supply chains. The issues of environmentally conscious manufacturing in addition to product recovery were researched by Gungor and Gupta [41] and focused on environmentally conscious design and production, remanufacturing, recycling, inventory control, and production planning. Moreover, Ilgin and Gupta [10] expanded upon this review to encompass literature published into 2010. A number of additional researchers have studied designs concerning product recovery under particular regulations and legislation [23,42-46].

\subsection{Present State of Research on Greenhouse Gas Emissions in Reverse Supply Chains}

The Intergovernmental Panel on Climate Change (IPCC) found that emissions linked to GHG across the globe have risen by over $80 \%$ between 1970 and 2010, producing a threat to the global ecosystem [47]. The U.S. Energy Information Administration reported that activities associated with manufacturing accounted for $84 \%$ of $\mathrm{CO}_{2}$ emissions linked to the energy industry, and $90 \%$ of industrial energy consumption [48]. Concerning carbon-constrained economy matters, replacing the original manufactured product with a remanufactured product generates large revenue in terms of carbon-saving returns [49]. Usually, the term original equipment manufacturer (OEM) is in reference to the company which first manufactured the product and/or used virgin materials. A number of studies have found, however, that remanufacturing has higher levels of profitability for OEMs [45,50]. In Japan, at least $80 \%$ of air conditioner materials are recycled due to the requirements associated with the home appliance recycling law. In 2014 alone, Japan recovered about 230,000 products, totaling 10,783 tons, with an $89 \%$ recycling ratio [51].

Recent literature reviews that consider the various elements of the sustainability of supply chains encompass energy use [52], the reduction of GHG emissions [6,7], waste management [53], green design [54], remanufacturing production planning and control [55], product recovery [56], and reverse logistics [57]. Reducing the emissions produced through a supply chain is increasingly being focused upon. The motivating factors behind supply chain decisions have expanded beyond cost, service and quality to also encompass carbon [58]. A "closed-loop supply chain" explored by Paksoy et al. [59] considered transportation costs alongside emissions of GHG, to measure the interplay amongst environmental and operational performance metrics. Abdallah et al. [60], meanwhile, studied 
greenhouse gas emissions as a result of network selection and design of supply chains through the use of a life cycle assessment (LCA) approach. Bhinge et al. [61] developed an optimization supply chain network design model, with the goal of maximizing the three main components of sustainability-social, environmental, and economic. The social indicator was used for health and safety, which encompassed both community and worker safety. The environmental measures used were rooted exclusively in the energy consumption of the various supply chain levels.

A mixed-integer programming model was formulated by Diabat and Simichi-Levi [62] to identify an ideal approach for organizations to encounter their carbon maximum while at the same time keeping costs to a minimum. Similarly, a mixed-integer linear programming model was formulated by Alkhayyal et al. [5,63] and Alkhayyal and Gupta [7] to identify the ideal movement of parts between numbers of remanufacturing centers under a specific carbon tax, while minimizing costs. Chaabane et al. [58] created a model that targeted processes in an aluminum firm and examined the impact of greenhouse gas emissions on designing a sustainable closed-loop sully chain (CLSC) network rooted in LCA principles; it also considered the interplay of environmental and economic facets through a number of costs and strategies. The issues surrounding the location of the facility with a trading price of GHG emissions alongside procurement costs were researched in Diabat et al.'s [64] study. Fahimnia et al. [65] studied both forward and reverse supply chain impacts on the carbon footprint by employing a mixed-integer linear programming (MILP) model, with emissions of GHG assessed through the utilization of carbon cost dollars. Benjaafar et al. [66] measured the impact of GHG emissions when a number of models for lot-sizing were incorporated into operational strategies, and the way in which significant reductions in emissions can be realized without increasing the cost just through adjustments to operations. A supply chain and form of transportation utilization study for a leading retailer, built atop carbon policies, was studied by Jin et al. [67]. Wang et al., [68] studied the effect of carbon emission constraints on production decisions in four mathematical models, finding that the manufacturer requires greater capital in order to realize maximum profits when carbon emission constraints are factored into the equation. Dornfeld, [69] discussed the requirements of green practices, methods, and tools in future manufacturing systems to make sure that they are sustainable.

Importantly, a few studies have examined the effect of integrating international, national, and corporate policies and legislation into a sustainable supply chain. For example, Nagurney et al. [70] addressed carbon taxes in electric power supply chains, and Subramanian et al. [71] proposed adding and integrating environmental considerations within the overall agenda. Biswas et al. [72] compared the impact on the environment of repaired, remanufactured, and new air compressors. Their study found that a remanufactured air compressor resulted in a 96\% reduction in GHG emissions compared to the alternatives. Likewise, Zanghelini et al. [73] showed that the remanufacturing process saved $46 \%$ in GHG emissions when compared to newly manufactured air compressor production systems. According to Seuring and Muller [39], sustainable supply chain management firstly comprised management of information, materials, and capital flow, as well as cooperation between the companies situated on the supply chain, while borrowing and applying goals from the three main tenets of sustainable development, social, economic, and environmental, to support both stakeholder and customer obligations.

Input-Output Life Cycle Assessment (EIO-LCA) Studies of Remanufacturing

Latham [74] used the EIO-LCA method to study the environmental and economic effects of manufactured traditional vehicles and remanufactured new vehicles. The results showed that in every EIO-LCA category remanufactured vehicles were a better alternative than manufactured vehicles, both economically and environmentally. EIO-LCA was used to study statistical data on U.S. cellular phone shipments and average costs of materials from 2003 and 2004 with respect to the environmental impact of upstream cellular phone production chains, such as greenhouse emissions, air pollutants, and energy use [75]. They concluded that reusing, recycling, refurbishing, and remanufacturing of mobile phones and their components were superior options to reduce environmental risk. Mihelcic et al. [76] 
studied product life cycle stages, finding that generally reusing and remanufacturing were preferred since they required fewer natural resources, less energy and time, and lower costs.

In this paper, supply chain economics are considered for optimizing total profit while minimizing GHG emissions, energy use, labor, product recovery, transportation, and rent costs. This is achieved by investigating the factors affecting costs by the type of facility (inter-facility, on-site, and total tonnes of carbon dioxide equivalent ( $\mathrm{tCO} 2 \mathrm{e})$ ) originating from the electricity utilization on-site per unit. Regulations concerning GHG emissions and environmental sustainability are in effect precluding substantial damage to the environment. The reduction of negative consequences included in the social dimension, including coastal destruction, noise, stress, traffic congestion, in addition to the spread of diseases and an overall improvement in the quality of life were not considered.

\section{Methodology}

The methodology employed herein was a mixed-integer linear programming (MILP) platform for reverse supply chains with embedded GHG emissions to determine the ideal flow of units between multiple remanufacturing centers in a RSC; this will maximize net profit and minimize GHG emissions, energy use, product recovery, transportation, labor, and rent costs. Factors determining expenditure were investigated with data drawn from actual sites within the Boston region. The value of the direct carbon tax used to estimate the GHG emissions varied in accordance with ranges presented at the 21st Conference of the Parties to the UNFCCC in Paris [4], the U.S. Interagency Working Group [77], and the U.S. Environmental Protection Agency [78]. This will regulate how the proposed policy influences profit limitations on remanufactured items. The consumption and expenditures data were taken from the 2012 Commercial Buildings Energy Consumption Survey (CBECS) and the 2010 Manufacturing Energy Consumption Survey (MECS) databases [79,80], based on the New England census division. A deterministic model with minimum shipment constraints was developed; the minimum shipment assumption was 5 units of $\mathrm{A} / \mathrm{C}$ based on the collection centers' phone interviews. The remanufacturing outcome was then compared to the deflated market price through the use of a consumer price index presented in terms of 2002 dollars [81], and that outcome was assessed through the use of the economic input-output life cycle assessment (EIO-LCA) model-a strategy for the estimation of the materials and energy resources necessary for environmental emissions produced through economic activities [82]. The sector of the EIO-LCA that was selected was the U.S. 2002 benchmark for the manufacturing of equipment for air conditioning, refrigeration, and warm air heating. Then, applying an orthogonal array testing allowed for full consideration of all possible inputs in each system. A deterministic model with relaxation constraints was developed to consider the impact of carbon price uncertainty on supply chain network decisions, and considered 13 different scenario groups for carbon pricing that deployed the same demand scenarios. Table 3 presents a summary of the solutions of the model, providing a range of carbon prices. The application of three varying configurations generated carbon prices between $\$ 0$ and $\$ 120$. LINGO 13.0 was used to identify a solution to the problem of optimization.

\subsection{Mixed-Integer Linear Programming Approach}

This approach optimizes the linear objective function that it deploys, subject to linear constraints. To provide an exhibit, the expression of a linear programming problem such as:

Maximize Z X (objective function)

Subject to $A X$ " $\leq$ " B and $X \geq 0$ (constraints)

where $X$ represents the vector of variable, $Z$ and $B$ represent the vectors of coefficients, and $A$ is the matrix of coefficients. When the variables of this linear problem are restricted to integers, the model is called a linear integer problem. Mixed-integer linear programming (MILP) is a special case, in which $0-1$ integer linear programming involves integers and non-integers for both constrained variables. It is a very general context for solving problems with both discrete decisions and continuous variables. It can be applied to business, economic, and engineering problems $[83,84]$. 


\subsection{Design of Experimental Studies}

This study was conducted to study the impact of different cost aspects using orthogonal arrays and regression analysis.

\section{Orthogonal Arrays}

An extensive study consisting of quantitative evaluation and performance of the model was conducted. A full-factorial design featuring 13 factors necessitates an extensive volume of experiments (that is, $\left.1.59 \times 10^{4}\right)$. Given this, experiments were designed through the use of orthogonal arrays $(\mathrm{OA})$, which allow for full testing of every possible system input with a minimum number of experiments. L27 OA was chosen, which requires 27 experiments that satisfy 13 factors, each with three different levels (a physical meaning which mimics a real-life example). Table 1 shows the factors and factor levels used in the experiments. For more details on Taguchi orthogonal array design and experimental run results see Tables S1-S28 in the Supplementary Material.

Table 1. Factors and factor levels used in the design of the experimental studies.

\begin{tabular}{cccccc}
\hline No & Factor & Unit & \multicolumn{3}{c}{ Levels } \\
\hline & & & $\mathbf{1}$ & $\mathbf{2}$ & $\mathbf{3}$ \\
\hline 1 & Transportation Cost & $\$$ & 0.5 & 1 & 1.5 \\
\hline 2 & Energy Cost - fixed & $\$ / \mathrm{kWh}$ & 0.07 & 0.12 & 0.27 \\
\hline 3 & Energy Cost - variable & $\$ / \mathrm{kWh}$ & 0.07 & 0.13 & 0.27 \\
\hline 4 & Rent Cost & $\$$ & 2.69 & 5.39 & 8.08 \\
\hline 5 & Labor Cost & $\$$ & 8.26 & 16.52 & 24.78 \\
\hline 6 & Social Cost of Carbon & $\$ / \mathrm{kg}$ & 0.00 & 40.00 & 120.00 \\
\hline 7 & Stock-out Cost & $\$$ & 50.00 & 90.00 & 130.00 \\
\hline 8 & Remanufacturing Cost & $\$$ & 8.26 & 16.52 & 24.78 \\
\hline 9 & Mean demand rate & Parts & 229 & 458 & 687 \\
\hline 10 & Retrieval Cost & $\$$ & 10.8 & 21.6 & 32.4 \\
\hline 11 & Inventory Cost & $\$$ & 2 & 4 & 6 \\
\hline 12 & Inventory level & Parts & 1250 & 2500 & 3750 \\
\hline 13 & Supply rate & Parts & 1049 & 2098 & 3147 \\
\hline
\end{tabular}

\section{Nomenclature}

Below (Table 2) is the nomenclature used herein:

Table 2. Notations.

\begin{tabular}{cc}
\hline Variables & Definition \\
\hline $\mathrm{C} 1 \mathrm{y}$ & The capacity of storage at remanufacturing facility y per remanufactured unit \\
\hline $\mathrm{C} 2 \mathrm{y}$ & Remanufacturing facility storage capacity y per used unit \\
\hline $\mathrm{Cx}$ & Collection center storage capacity $\mathrm{x}$ per unit \\
\hline $\mathrm{Cz}$ & Reselling center storage capacity $\mathrm{z}$ per unit \\
\hline $\mathrm{Dx}$ & Collection center demand for products $\mathrm{x}$ \\
$\mathrm{Dz}$ & Reselling center demand for products $\mathrm{z}$ \\
\hline $\mathrm{dxy}$ & Distance from collection center $\mathrm{x}$ to remanufacturing facility y, per mile \\
$\mathrm{dyz}$ & Distance from remanufacturing facility y to reselling center $\mathrm{z}$, per mile \\
\hline $\mathrm{EXx}$ & Collection center energy cost $\mathrm{x}$ per unit \\
\hline $\mathrm{EXy}$ & Remanufacturing facility energy cost y per unit \\
\hline $\mathrm{EXz}$ & Reselling center energy cost $\mathrm{z}$ per unit \\
\hline
\end{tabular}


Table 2. Cont.

\begin{tabular}{|c|c|}
\hline Variables & Definition \\
\hline GH & GHG emissions per ton-mile \\
\hline GHx & Collection center GHG emissions $x$, per unit; \\
\hline GHy & Remanufacturing facility GHG emissions y, per unit \\
\hline $\mathrm{GHz}$ & Reselling center GHG emissions z, per unit \\
\hline $\mathrm{Hx}$ & Per unit holding cost at collection center $x$ \\
\hline Lx & Collection center labor cost $\mathrm{x}$ per unit \\
\hline Ly & Remanufacturing facility labor cost y per unit \\
\hline $\mathrm{Lz}$ & Reselling center labor cost $\mathrm{z}$ per unit \\
\hline $\mathrm{O} 1$ & Remanufacturing unit occupied space \\
\hline $\mathrm{O} 2$ & Used-product unit occupied space \\
\hline $\mathrm{Kg}$ & Unit weight (per unit) \\
\hline $\mathrm{P}$ & Per unit reprocessing cost \\
\hline RT & Per unit retrieval cost \\
\hline RCAPy & Remanufacturing facility y capacity \\
\hline $\mathrm{RCx}$ & Collection center rent cost $\mathrm{x}$ per unit \\
\hline $\mathrm{RCy}$ & Remanufacturing facility rent cost y per unit \\
\hline $\mathrm{RCz}$ & Reselling center rent cost $\mathrm{z}$ per unit; \\
\hline SOx & Per unit stock-out cost at collection center $x$ \\
\hline SUPx & Collection center supply $\mathrm{x}$ \\
\hline Txy & Transportation expense from collection center $x$ to remanufacturing facility $y$, per unit \\
\hline Tyz & Transportation expense from remanufacturing facility y to reselling facility $\mathrm{z}$, per unit \\
\hline $\mathrm{x}$ & Collection center \\
\hline $\mathrm{y}$ & Remanufacturing facility \\
\hline $\mathrm{z}$ & Reselling center \\
\hline Xxy & Decision variable for the quantity of units shifting from collection center $\mathrm{x}$ to remanufacturing facility $\mathrm{y}$ \\
\hline Yxz & Decision variable for the quantity of units shifting from remanufacturing facility y to reselling center $\mathrm{z}$; \\
\hline $\mathrm{Zy}$ & Binary variable $(0 / 1)$ for the selection of remanufacturing facility y \\
\hline $\mathrm{Zz}$ & Binary variable $(0 / 1)$ for the selection of reselling center $z$ \\
\hline
\end{tabular}

\section{Assumptions}

There were assumptions that emissions of GHG originated from four primary causes, adapted from our previous work, Alkhayyal and Gupta [6,7]:

1. Collection centers: emission volumes are proportional to the usage at of power each center;

2. Remanufacturing facilities: emission volumes are in proportion to the volume of each facility;

3. Reselling centers: emission volumes are proportional to the usage at of power each center;

4. Transportation: transporting the products, emissions volumes are rooted in the distance traveled between facilities and centers, and the weight of each unit is $(40 \mathrm{Kg})$.

The model employs an assumption that the inventory cost of used products at the remanufacturing facility was one-quarter of the retrieval cost $(\mathrm{R})$, and for remanufactured products was one quarter of the reprocessing cost $(\mathrm{P})$.

\section{Problem Formulation}

Herein, the model employed was generated in a single-period mixed integer linear programming model of reverse supply chains. The model considered a full estimation of emissions in order to regulate the ideal movement of parts between multiple remanufacturing facilities that will help in 
optimizing profitability while minimizing $\mathrm{CO} 2$ emissions, product recovery, transportation, energy use, rent costs, and labor.

Minimize:

Retrieval cost:

$$
\sum_{x=1}^{3} \sum_{y=1}^{2} \sum_{y} R T . X x y+
$$

Transportation cost:

$$
\sum_{x=1}^{3} \sum_{y=1}^{2} T x y . X x y+\sum_{y=1}^{2} \sum_{z=1}^{3} T y z . X y z+
$$

Remanufacturing cost:

$$
\sum_{y=1}^{2} \sum_{z=1}^{3} P . Y y z+
$$

Inventory cost:

$$
\sum_{x=1}^{3} \sum_{y=1}^{2}\left(\frac{R T x}{4}\right) X x y+\sum_{y=1}^{2} \sum_{z=1}^{3}\left(\frac{P y}{4}\right) Y y z+
$$

Rent cost:

$$
\sum_{x=1}^{3} R C x . D x+\sum_{y=1}^{2} R C y . X x y+\sum_{z=1}^{3} R C z . Y y z+
$$

Labor cost:

$$
\sum_{x=1}^{3} L x . D x+\sum_{y=1}^{2} L y . X x y+\sum_{z=1}^{3} L z . Y y z+
$$

Energy cost:

$$
\sum_{x=1}^{3} E x . D x+\sum_{y=1}^{2} E y . X x y+\sum_{z=1}^{3} E z . Y y z+
$$

Greenhouse gas (GHG) emissions:

$$
\begin{aligned}
\sum_{x=1}^{3} G H x \cdot D x & +\sum_{x=1}^{3} \sum_{y=1}^{2} G H y \cdot X x y+\sum_{y=1}^{2} \sum_{z=1}^{3} G H z \cdot Y y z \\
& +\sum_{x=1}^{3} \sum_{y=1}^{2} G H \cdot D x y \cdot K g \cdot X x y \sum_{y=1}^{2} \sum_{z=1}^{3} G H \cdot d y z . K g . Y y z
\end{aligned}
$$

$$
\text { Stock-out costs }\{(\mathrm{Dz}-\mathrm{SUPx})(1-\mathrm{Z})\} \times \mathrm{SOx}
$$

Subject to:

Constraints concerning demand must be achieved while total production and inventory costs are minimized:

$$
\sum_{y} Y y z=D z ; \forall z
$$

The total output in remanufacturing facility is at maximum:

$$
\sum_{x} X x y \geq \sum_{y} Y y z D z ; \forall y
$$

Remanufactured products consumed space within each remanufacturing facility is at its maximum capacity, and the total space utilized at each collection center considered by returned items is at its maximum capacity:

$$
\begin{gathered}
\sum_{z} O 1 . Y y z \leq C 1 y \cdot Y y ; \forall y \\
\sum_{y} O 2 . X x y \leq C ; \forall x
\end{gathered}
$$


The total space utilized within each remanufacturing facility by products that are returned is at its maximum capacity:

$$
\sum{ }_{x} O 2 . X x y \leq C 2 y . Z y ; \forall y
$$

The total space utilized at a reselling center by returned products is at its maximum capacity:

$$
\sum_{y} O 1 . Y y z \leq C z . Z z ; \forall z
$$

Constraints for non-negativity:

$$
\begin{aligned}
& X_{u v} \geq 0 ; \forall x, y \\
& Y_{u v} \geq 0 ; \forall y, z
\end{aligned}
$$

The total quantity of returned products that are provided to the remanufacturing facilities by collection centers is the maximum supply:

$$
\begin{aligned}
& \sum_{z} Y y z \leq R C A P y ; \quad \forall \mathrm{y} \\
& \sum_{y} X x y \leq S U P x ; \forall \mathrm{x}
\end{aligned}
$$

\section{Case Study}

The case study was based in real locations in the metropolitan area of Boston, Massachusetts, in the United States and explored three collection centers (located in Melrose, Canton, and Natick), two remanufacturing facilities located in Hingham and Taunton, and three reselling centers in Boston, Revere, and Somerville, as seen in Figure 1. The real distances in miles between the sites were explored, fuel costs and emissions of $\mathrm{CO} 2$, assuming the gasoline price per gallon of $\$ 2.14$-the price during October 2015 [7]. The quantity of laborers, their annual salaries, and the size of the production space were also explored. In summary, the study presents a breakdown of the factors comprising cost- $\mathrm{CO} 2$ emissions, energy, labor, rent, and transportation —all by facility type, on-site, off-site, and total tCO2e from on-site electricity usage by unit. The U.S. Energy Information Administration data reports at the U.S. Department of Energy ([85]; Supplementary Material Figures S1-S4) were used to quantify the energy utilization per facility. The Commercial Buildings Energy Consumption Survey (CBECS), originally conducted through a consideration of collection centers and reselling centers' energy data was assessed, and for this survey, the New England region with retail (other than mall) building activity was chosen. Data from electricity, natural gas, and fuel oil energy sources were examined along with their usage in each building. See Supplementary Material Figures S1 and S2 for more details. The Manufacturing Energy Consumption Survey (MECS) was used for remanufacturing facilities' energy data, and for this survey, the New England region and the appliances subsector were chosen. Data from electricity, natural gas, distillate fuel oil and diesel, and residual fuel oil energy sources were examined along with their usage inside each facility. See Supplementary Material Figures S3 and S4 for more details. This particular example explored a mid-size LG A/C unit, model LW1213ER, with measurements of $246 / 9^{\prime \prime} \times 16 "$ x $232 / 6 "$, and a market price of $\$ 349.99$ [86,87]. Two 12-foot trucks with a load volume of 475 cubic feet and a capacity of $58 \mathrm{~A} / \mathrm{C}$ units each were assumed, based on interviews, for transportation [88]. Estimation of emissions was accomplished through the use of a direct carbon tax, with a value ranging between $\$ 40$ and $\$ 120$ per ton CO2 equivalent-as proposed in the 21st Conference of the Parties to the UNFCCC [4] in Paris, the U.S. Environmental Protection Agency [78], and the U.S. Interagency Working Group [77] — to clarify how proposed policies might impact the margin of profitability for remanufactured goods. Table 3 shows the data collected from each collection center; the number of $\mathrm{A} / \mathrm{C}$ units received was fixed in the model, and the total items included all the items that fell under the same category as the A/Cs, which were the white goods/appliances in each collection center report. Also, for all rent, labor costs, and trip distances between locations, see Supplementary Material Tables S29 and S30. A deterministic model was developed, and orthogonal array testing was included to allow for full evaluation of all possible system inputs. 


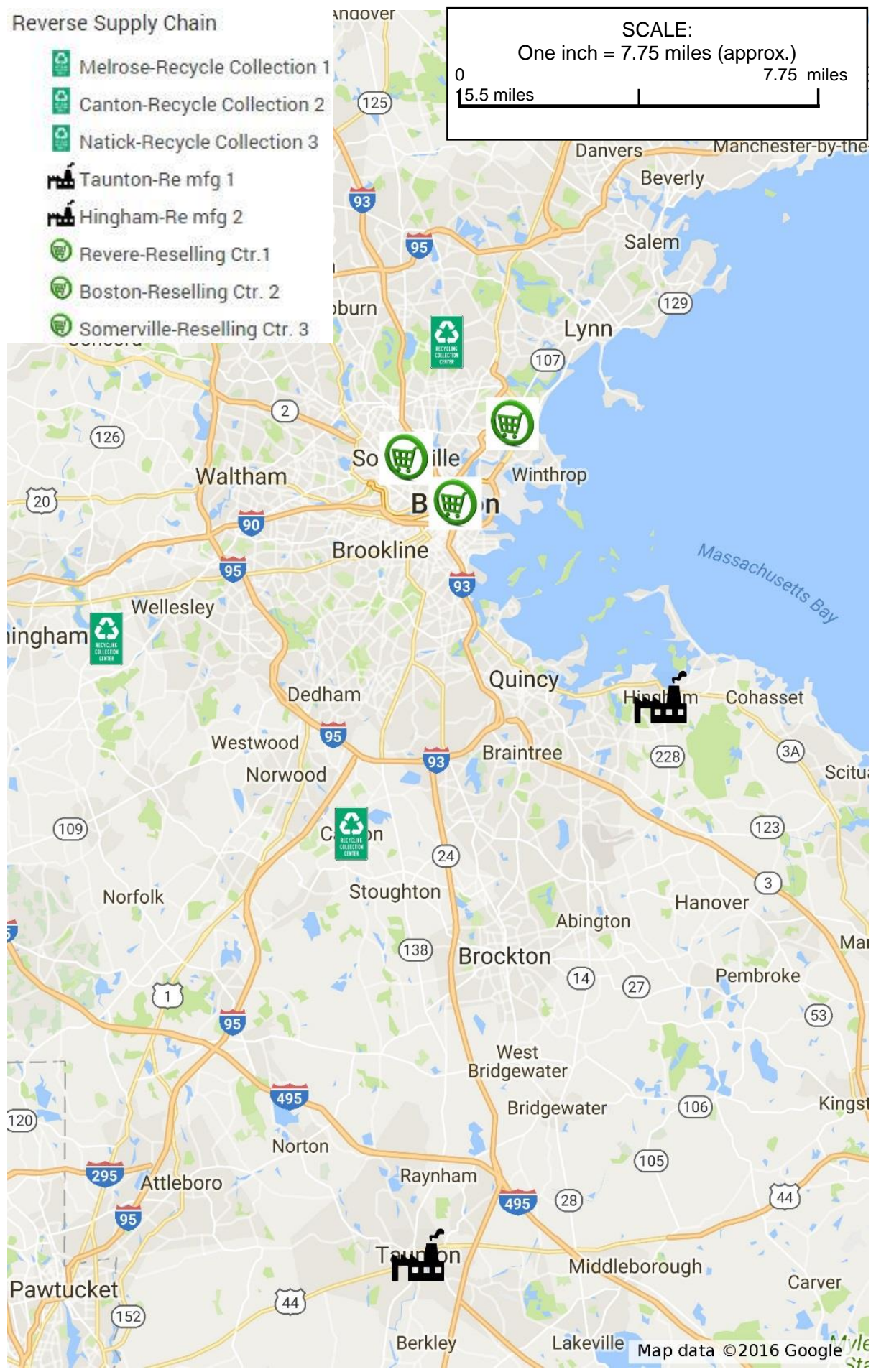

Figure 1. The actual sites in the Boston, Massachusetts area.

Table 3. Factors and factor levels used in design of experimental studies.

\begin{tabular}{ccccc}
\hline Collection Center & $\begin{array}{c}\text { AC Unit Received } \\
\text { (Year) }\end{array}$ & $\begin{array}{c}\text { Pick up/Drop off } \\
\text { Fee } \$ \text { per Item }\end{array}$ & $\begin{array}{c}\text { Total Items per } \\
\text { Year }\end{array}$ & $\begin{array}{c}\text { Total Income } \\
\text { (\$/Year) }\end{array}$ \\
\hline Canton & 107 & $\$ 20$ & 509 & $\$ 10,180$ \\
\hline Natick & 176 & $\$ 25$ & 837 & $\$ 20,925$ \\
\hline Melrose & 175 & $\$ 20$ & 752 & $\$ 15,040$ \\
\hline
\end{tabular}




\section{Results}

In this section, results of the deterministic model with minimum shipments are explained in Section 7.1, the effects of varying social cost of carbon values for remanufacturing units are in Section 7.2, and the design of experiments to study cost factor effects is found in Section 7.3.

\subsection{Deterministic Model with Minimum Shipments}

In the case of not considering a carbon tax, the unit price was $\$ 212$ with a margin of profit estimated at $26.40 \%$ for a $\$ 288$ selling price, in line with the current refurbished market price [87], while a USEPA-recommended $\$ 40 /$ ton $\mathrm{CO} 2$ equivalent ( $\mathrm{tCO} 2 \mathrm{e}$ ) tax decreased the profitability to $19.10 \%$, assuming a fixed price for remanufacturing of $\$ 233$ per unit [78]. The results obtained are shown in Figure 2, which demonstrates the network patterns of returned products through the reverse logistics (RL) network. The total remanufacturing cost was $\$ 233$ per unit, and this devolved model was $\$ 116.99 /$ unit under the current market price. The emission quantity was 0.07 tCO2e per unit. Comparing remanufacturing results to the EIO-LCA demonstrated that remanufacturing emission volumes were $0.084 \mathrm{tCO} 2 \mathrm{e}$ per unit lower than new manufacturing. Figure 3 exhibits the effects of the social cost of carbon on the unit price by comparing the developed remanufacturing model and the EIO-LCA manufacturing model for the new manufacturing producer prices over a range of proposed SCC values according to a recent U.S. government study, and at $\$ 220$ per ton as used by Moore and Diaz [89]. Therefore, existing approaches used different carbon policies.

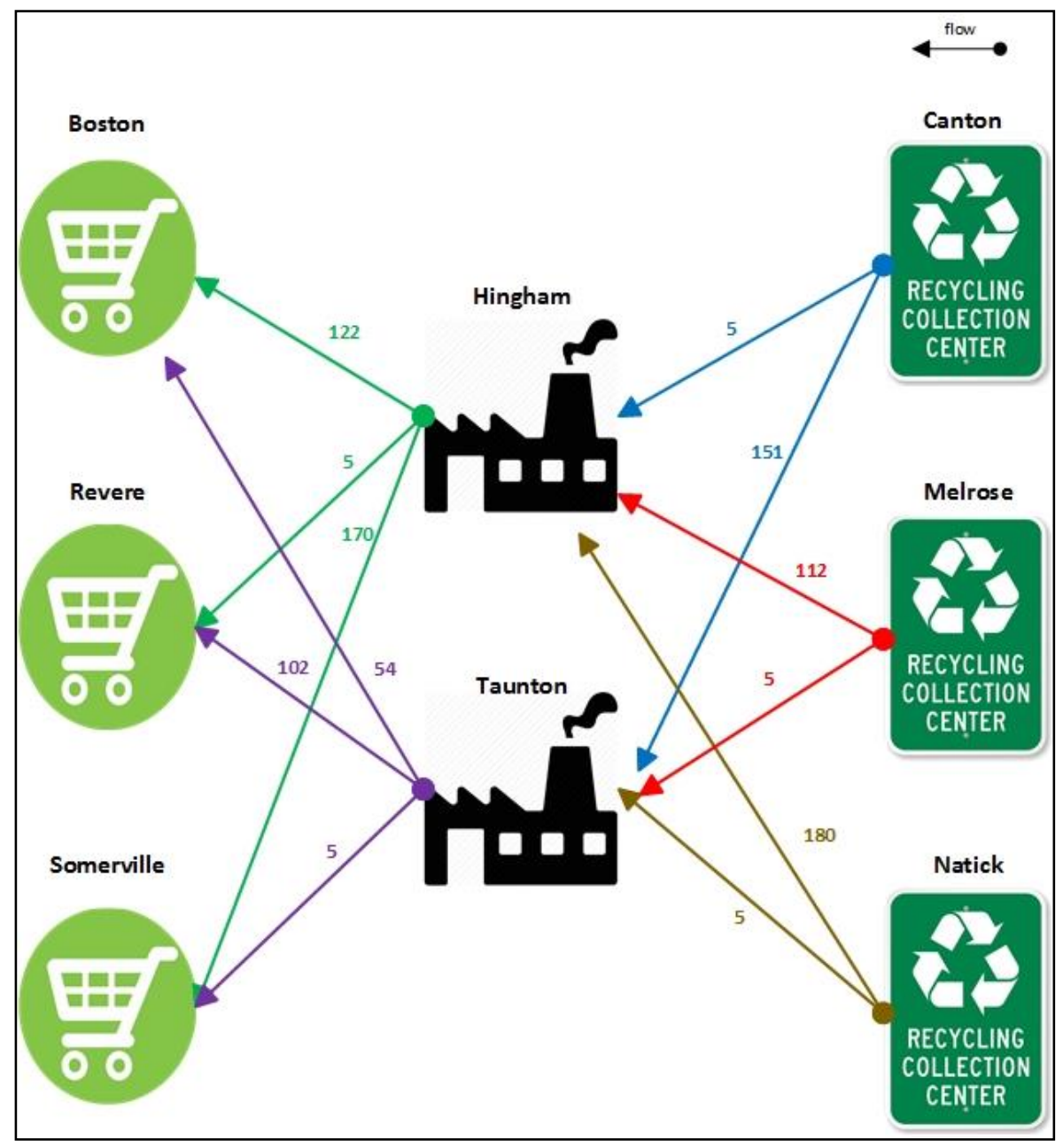

Figure 2. Optimal number of items transported within the reverse supply chain (RSC). 


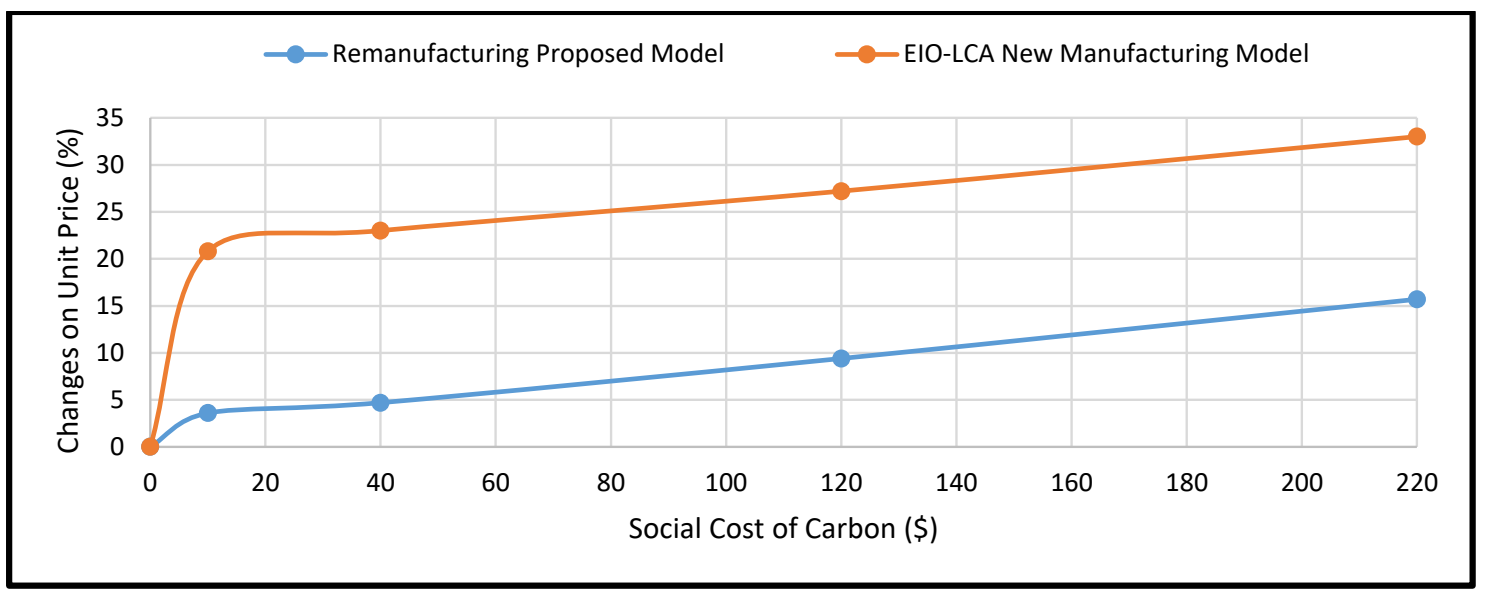

Figure 3. Social cost of carbon effects on unit price.

\subsection{Deterministic Model with Relaxation Constraints}

In order to consider uncertainty effect of carbon price on supply chain network decisions and strategies, the model considered 13 scenario clusters for the tax price, all with equal demand scenarios. The solutions of the deterministic model for different carbon prices are summarized in Table 4 . There were three different configuration results for carbon prices ranging between $\$ 0$ and $\$ 120$. The locations of remanufacturing facilities, collection centers, and the reselling center for each configuration are shown in Figure 4.

Table 4. Case study results of the deterministic model for different carbon price scenarios.

\begin{tabular}{ccccccc}
\hline $\begin{array}{c}\text { Carbon } \\
\text { Price (\$/ton) }\end{array}$ & Cases & $\begin{array}{c}\text { Total } \\
\text { Carbon } \\
\mathbf{( t o n )}\end{array}$ & $\begin{array}{c}\text { Carbon Cost } \\
\mathbf{( \$ )}\end{array}$ & $\begin{array}{c}\text { Total Cost } \\
\mathbf{( \$ )}\end{array}$ & $\begin{array}{c}\text { Changes in } \\
\text { Unit Price } \\
\mathbf{( \% )}\end{array}$ & $\begin{array}{c}\text { Emissions Improvement } \\
\text { Compared to the Base } \\
\text { Scenario (\%) }\end{array}$ \\
\hline $\mathbf{0}$ & 1 & 101 & 0 & 106962.00 & $0.00 \%$ & $0.00 \%$ \\
\hline $\mathbf{1 0}$ & 1 & 99.00 & 990.00 & 108072.02 & $1.04 \%$ & $1.98 \%$ \\
\hline $\mathbf{2 0}$ & 1 & 98.30 & 1966.00 & 108935.23 & $1.84 \%$ & $2.67 \%$ \\
\hline $\mathbf{3 0}$ & 2 & 96.80 & 2904.00 & 109798.44 & $2.65 \%$ & $4.16 \%$ \\
\hline $\mathbf{4 0}$ & 2 & 95.79 & 3831.60 & 110661.65 & $3.46 \%$ & $5.16 \%$ \\
\hline $\mathbf{5 0}$ & 3 & 94.69 & 4734.50 & 111524.86 & $4.27 \%$ & $6.25 \%$ \\
\hline $\mathbf{6 0}$ & 3 & 92.58 & 5554.62 & 112388.07 & $5.07 \%$ & $9.34 \%$ \\
\hline $\mathbf{7 0}$ & 3 & 91.46 & 6402.48 & 113251.28 & $5.88 \%$ & $10.54 \%$ \\
\hline $\mathbf{8 0}$ & 3 & 90.35 & 7228.08 & 114114.49 & $6.69 \%$ & $11.65 \%$ \\
\hline $\mathbf{9 0}$ & 3 & 89.24 & 8031.42 & 114977.70 & $7.49 \%$ & $12.75 \%$ \\
\hline $\mathbf{1 0 0}$ & 3 & 88.13 & 8812.50 & 115840.91 & $8.30 \%$ & $13.85 \%$ \\
\hline $\mathbf{1 1 0}$ & 3 & 87.01 & 9571.32 & 116704.12 & $9.11 \%$ & $14.95 \%$ \\
\hline $\mathbf{1 2 0}$ & 3 & 85.90 & 10307.88 & 117567.33 & $9.92 \%$ & \\
\hline
\end{tabular}

Note: The coloring is based on conditional formatting, as long we the color is not red then the \% is low and not costly. 


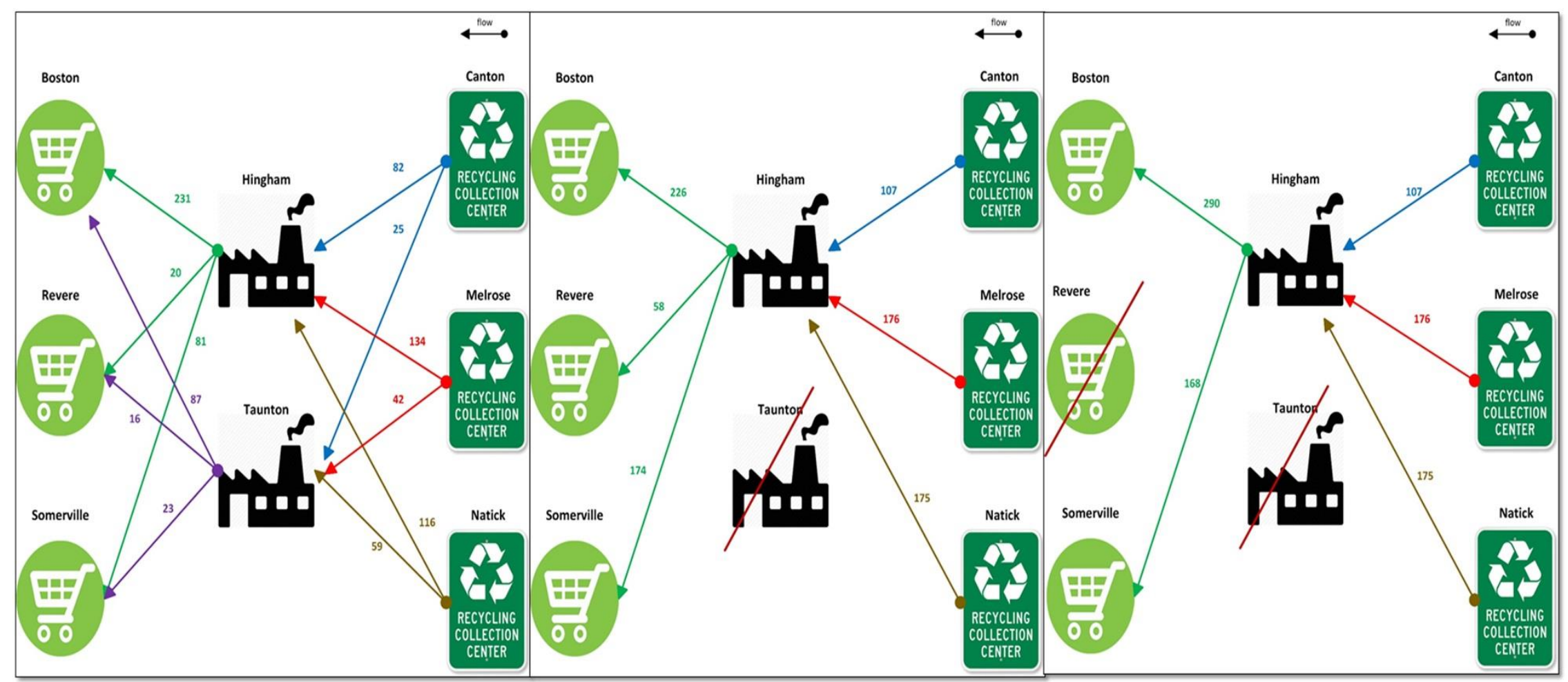

Figure 4. The supply chain network for configurations 1-3. 
No carbon tax considered (i.e., a carbon price of $\$ 0$ ) and $\$ 10$ and $\$ 20$ prices, resulted in "configuration 1" This is the current standard configuration, with three reselling centers, two remanufacturing facilities, and three collection centers. Increasing the carbon price to $\$ 30$ per ton led to a change from configuration 1 to configuration 2, which had fewer facilities, leading to a supply chain configuration that was ultimately greener. As production is the leading contributor to GHG emissions (see Figure 5), the location change in configuration 2 reduced production and incoming transportation costs and emissions.

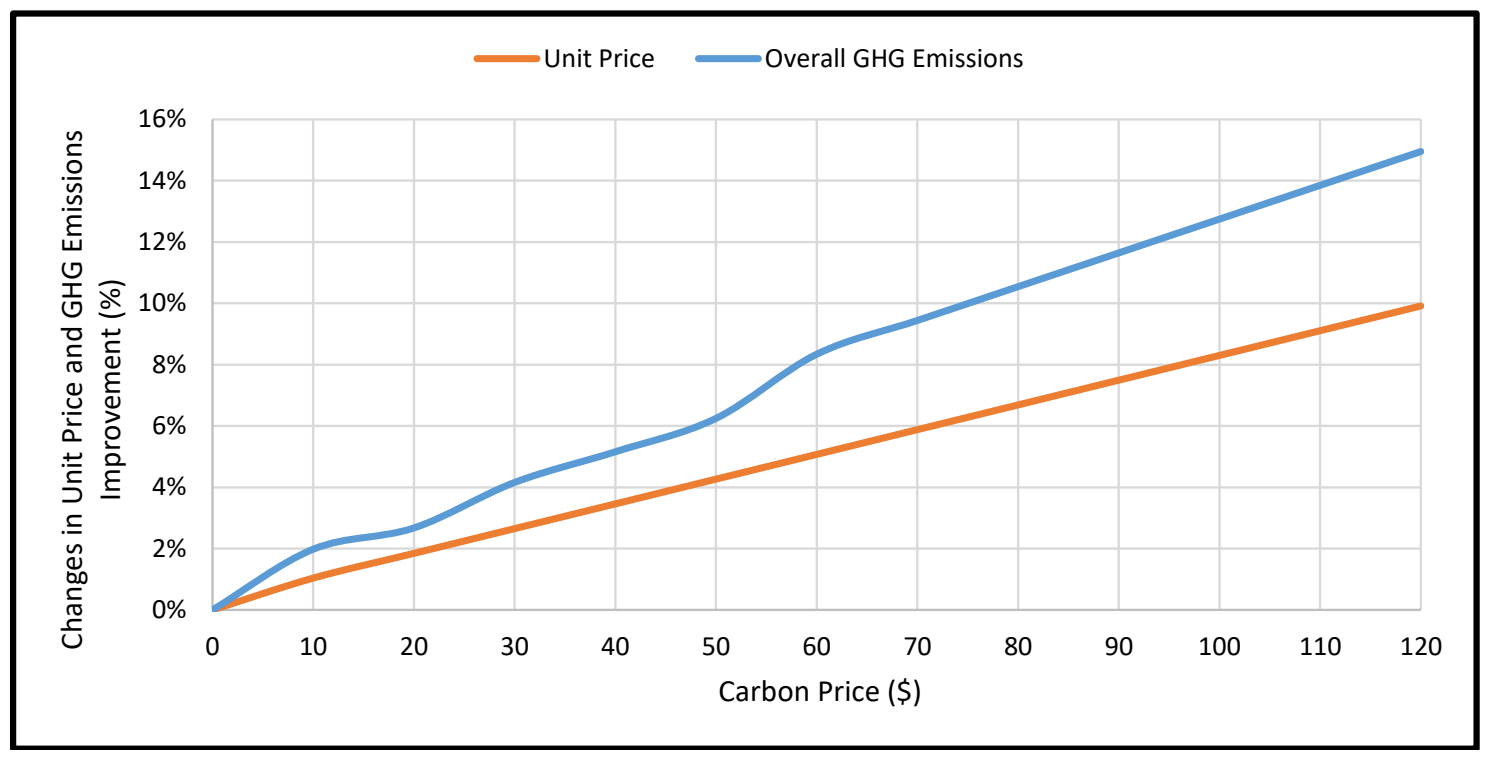

Figure 5. Unit price and emissions reduction performance changes at various carbon prices.

Configuration 3 was chosen for a carbon price of $\$ 50$ and above; it had three collection centers, one remanufacturing facility, and two reselling centers. A decrease in the number of facilities helps to reduce the inbound and outbound transportation costs and emissions and allows more efficient and environmentally-friendly transportation routes.

Figure 5 combined the unit price and emissions reduction performance changes at various carbon prices. It shows that the unit price increases in a linear fashion alongside the increase in the carbon price. After introducing the carbon price, the emissions improvement significantly increases to $2 \%$. After that, the emissions improvement slowly increases until it reaches $\$ 50$, then there is another jump with the introduction of configuration 3 . Therefore, there is a significant correlation between the carbon price changes and both unit price and emissions improvement, since if carbon price increases, both unit price and emissions improvement also increase.

\subsection{Effect of Different Social Cost of Carbon}

To estimate the unit price based on the social cost of carbon, which can fall anywhere between $\$ 0 /$ ton to $\$ 120 /$ ton [77], we considered the case study above. Figure 6 shows the effect of different SCC on unit price, and it is clear from the graph that the unit price of becomes much higher as the SCC approaches $\$ 68 /$ ton and above. This piecewise linear line has four different segments; as seen in Figure 6, each segment has a successive pair of points connected with a straight line. These segments represent system states.

The focus in this analysis was to discover the relationship between the increasing price for the 458 units that were in the case study and the corresponding emissions rate. Figure 7 shows that, with the carbon price increasing from $\$ 0$ to $\$ 20$ per ton of emission, production activities show only minor changes, while increasing the price to $\$ 40$ per ton results in more significant emissions reduction. However, the significant cost increase at these facilities reflected emissions improvement in these 
activities (Figure 7). In Figure 7, "production" includes production and inventory at remanufacturing facilities and "collection" includes collection, recycling, disposal, and inventory at collection centers. "Transportation" comprises all shipment activities of returned products coming through collection centers to remanufacturing facilities, then on to reselling centers.

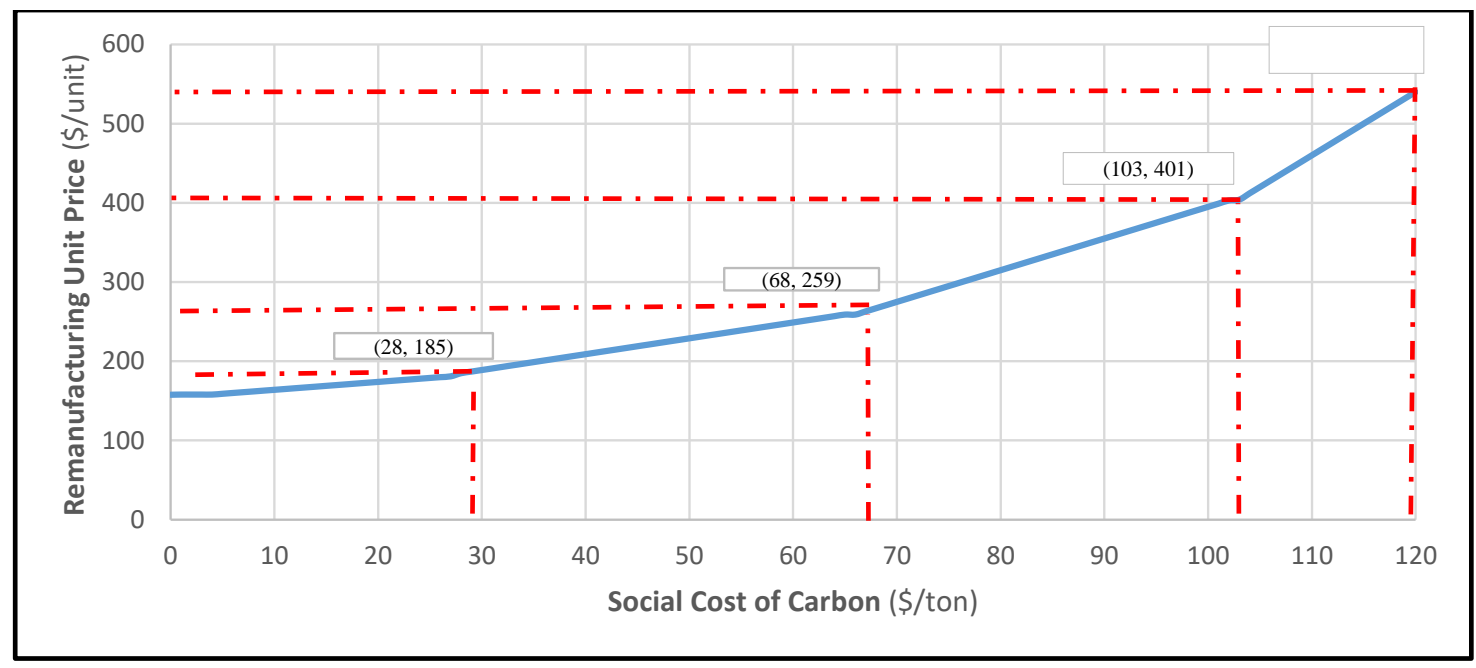

Figure 6. Effect of different carbon prices on unit price.

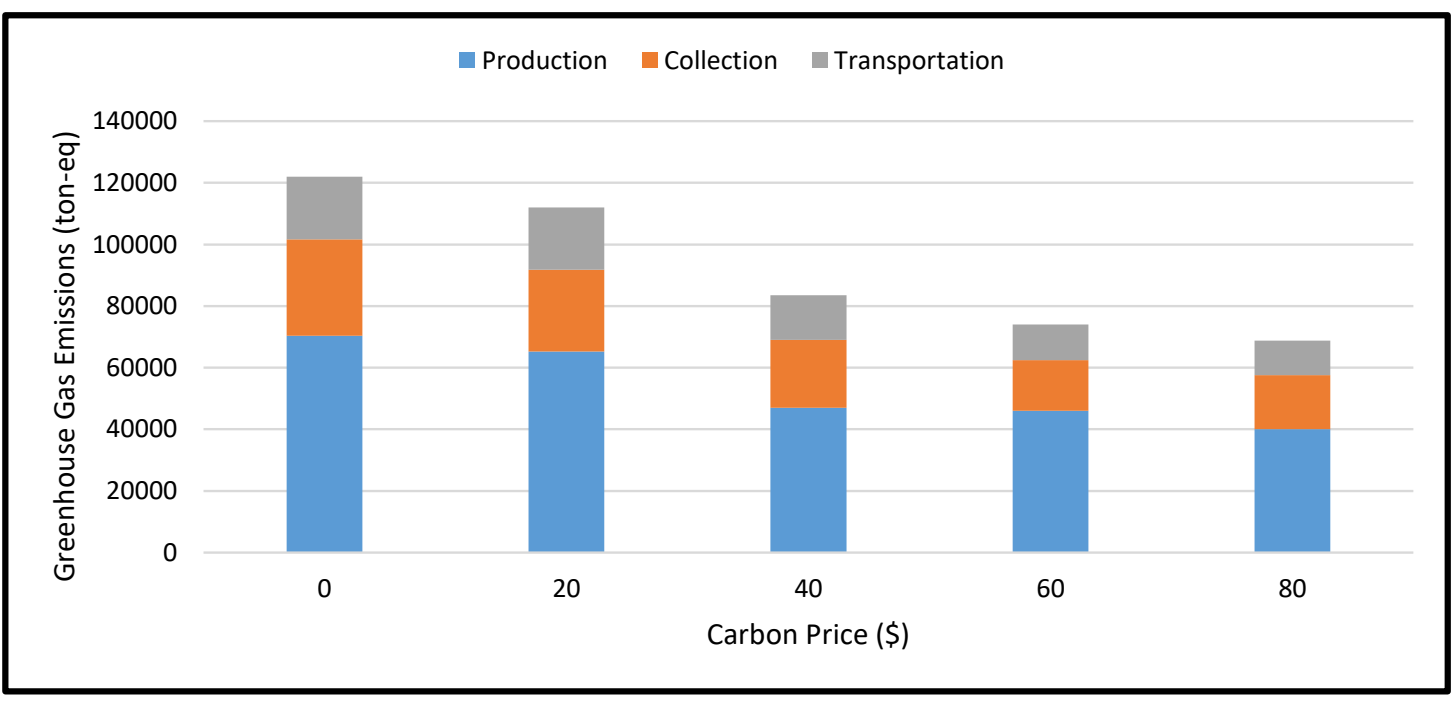

Figure 7. Generated carbon emissions at various carbon prices.

Statistical Analysis

A statistical analysis was performed by estimating analysis of variance (ANOVA) of the regression analysis, using MINITAB 17 to examine the effects of factors mentioned in Table 1 on the unit price, and to determine whether the differences between factors were statistically significant. In order to test the null hypothesis which stated that all factor means were equal. Table 5 shows the output summary of the ANOVA. If any p-value was less than or equal the significance level of 0.05 , the null hypothesis (all means are equal) would be rejected and it would be concluded that there were significant differences between the means. Supplementary Material Figure S5 shows the residuals plotted against the predicted values, showing an ideal random scatter around a value of zero. This indicates that the residuals were homogenous. 
Table 5. Analysis of variance output summary.

\begin{tabular}{cccccc}
\hline Source & DF & Adj SS & Adj MS & F-Value & P-Value \\
\hline Regression & 13 & $5.32 \times 10^{10}$ & $4.10 \times 10^{9}$ & 9.33 & 0.000 \\
\hline Transportation Cost & 1 & $2.86 \times 10^{10}$ & $2.86 \times 10^{10}$ & 65.27 & 0.000 \\
\hline Energy Cost - fixed & 1 & $6.93 \times 10^{6}$ & $6.93 \times 10^{6}$ & 0.02 & 0.902 \\
\hline Energy Cost - variable & 1 & $1.43 \times 10^{8}$ & $1.43 \times 10^{8}$ & 0.33 & 0.578 \\
\hline Rent Cost & 1 & $4.02 \times 10^{8}$ & $4.02 \times 10^{8}$ & 0.92 & 0.356 \\
\hline Labor Cost & 1 & $6.41 \times 10^{6}$ & $6.41 \times 10^{6}$ & 0.01 & 0.906 \\
\hline Social Cost of Carbon & 1 & $4.54 \times 10^{8}$ & $4.54 \times 10^{8}$ & 1.03 & 0.328 \\
\hline Inventory Cost & 1 & $3.43 \times 10^{8}$ & $3.43 \times 10^{8}$ & 0.78 & 0.392 \\
\hline Remanufacturing Cost & 1 & $5.05 \times 10^{9}$ & $5.05 \times 10^{9}$ & 11.52 & 0.005 \\
\hline Mean demand rate & 1 & $1.15 \times 10^{7}$ & $1.15 \times 10^{7}$ & 0.03 & 0.873 \\
\hline Retrieval Cost & 1 & $2.85 \times 10^{9}$ & $2.85 \times 10^{9}$ & 6.49 & 0.024 \\
\hline Inventory Cost & 1 & $1.28 \times 10^{8}$ & $1.28 \times 10^{8}$ & 0.29 & 0.598 \\
\hline Inventory level & 1 & $7.69 \times 10^{8}$ & $7.69 \times 10^{8}$ & 1.75 & 0.208 \\
\hline Supply rate & 1 & $3.96 \times 10^{9}$ & $3.96 \times 10^{9}$ & 9.03 & 0.010 \\
\hline Error & 13 & $5.7 \times 10^{9}$ & $4.39 \times 10^{8}$ & & \\
\hline Total & 26 & $5.89 \times 10^{10}$ & & &
\end{tabular}

In practice, transportation costs are a key aspect of supply chains, and have a very high impact on cost. Here, after tracking the route, it was statistically and practically significant. Moreover, the costs of transportation for the current case study, including distance, loads, and gas prices, were very high. High Massachusetts salaries/wages, labor that directly interfered with disassembly and assembly of products for remanufacturing, and retrieval costs had high impacts. The supply rate also had a significant impact, as when it increased the unit price decreased dramatically, due to economic scale quantity, and vice versa.

It is important to satisfy the normality assumption so that test results are reliable. To gain an idea of the normal error assumption, a normal probability plot of the residuals was generated and is shown in Supplementary Material Figure S6. The normal probability plot demonstrated that the residuals strongly supported the normality assumption and appeared to generally follow a straight line.

\section{Conclusions and Recommendations}

This research has put forth a reverse supply chain optimization model that has been assembled to factor in the impact of supply chain operational and strategic actions on the environment. A case study based in real locations was explored to exhibit the model's performance, while also seeking to clarify how the policy that has been proposed could impact the profit margins of remanufactured items, and to test the influence of emissions pricing on optimal configurations of a RSC. The findings demonstrated that the carbon price ranges that were employed in this research will control the quantity of GHG emissions produced within the context of reverse supply chain operations. Moreover, by applying the RSC reconfiguration model, it was shown that the pricing of carbon emissions, especially at higher price points, mostly impacts production and transportation operations, thus resulting in reduced costs and emissions. Similarly, a high carbon price resulted in varying supply chain configurations, although not always in a linear manner. The RSC configuration was influenced by the price of carbon. This research presented the theoretical modeling of optimal RSC systems, and also an empirical case study concerning remanufactured appliances, an area of the industrial literature that has not been extensively studied. 
Based on this case study, it is recommended that the deterministic model be relaxed to support the capacity to relocate remanufacturing facilities/reselling centers, as opposed to ceasing the operations of the facility, based on the following elements:

- Parking difficulties and congestion caused by traffic;

- Commuting distance;

- Current cost criteria;

- Population, economy, and geography of the city/setting.

The costs associated with remanufacturing are linked not only to the economy, but to the environment as well. Thus, the proximity of facilities to cities and centers of high reclamation and recycling levels is important to ensure not only that costs are minimized, but also the environmental impact of operations.

Supplementary Materials: The following are available online at http:/ / www.mdpi.com/2071-1050/11/7/2097/ s1, Supplementary Material contains four parts: Part I: Methods, which has the tables for the orthogonal arrays of 27 experiments to satisfy 13 factors, each with three different levels used for quantitative evaluation and performance of the mixed-integer linear programming model; Part II, Results of experiments; Part III, Data; and Part IV, Statistical analysis results.

Acknowledgments: The author acknowledges the financial support received from Prince Sultan University (PSU), and their support and encouragement in carrying out this study.

Conflicts of Interest: The author has declared no conflict of interest.

\section{References}

1. Stahel, W.R.; Reday-Mulvey, G. Jobs for Tomorrow: The Potential for Substituting Manpower for Energy; Vantage Press: New York, NY, USA, 1981.

2. Frosch, R.A.; Gallopoulos, N.E. Strategies for manufacturing. Sci. Am. 1989, 261, 144-153. [CrossRef]

3. Stahel, W.R. The circular economy. Nat. News 2016, 531, 435. [CrossRef]

4. Conference of the Parties (COP21). The Paris Agreement. The United Nations Framework Convention on Climate Change (UNFCCC). Available online: http://www.cop21paris.org/ (accessed on 12 November 2016).

5. Alkhayyal, B.; Gupta, S.M.; Eckelman, M.J. Managing environmental issues in reverse supply chain. In Proceedings of the Institute of Industrial Engineers (IIE) Annual Research Conference, Anaheim, CA, USA, 21-24 May 2016.

6. Alkhayyal, B.A.; Gupta, S.M. The Impact of Carbon Emissions Policies on Reverse Supply Chain Network Design. Doğuş Üniversitesi Dergisi 2018, 1, 99-111. [CrossRef]

7. Alkhayyal, B.A.; Gupta, S.M. A Linear Physical Programming Approach for Evaluating Collection Centers for End-of-Life Products. In Applications of Management Science; Emerald Publishing Limited: Bingley, UK, 2018; pp. 65-79.

8. Vadde, S.; Kamarthi, S.V.; Gupta, S.M. Pricing decisions for product recovery facilities in a multi-criteria setting using genetic algorithms. In Environmentally Conscious Manufacturing VI; International Society for Optics and Photonics: San Diego, CA, USA, 2006; Volume 6385.

9. Nash, J.; Bosso, C. Extended Producer Responsibility in the United States: Full Speed Ahead? J. Ind. Ecol. 2013, 17, 175-185. [CrossRef]

10. Ilgin, M.A.; Gupta, S.M. Environmentally conscious manufacturing and product recovery (ECMPRO): A review of the state of the art. J. Environ. Manag. 2010, 91, 563-591. [CrossRef]

11. Amezquita, T.; Hammond, R.; Salazar, M.; Bras, B. Characterizing the remanufacturability of engineering systems. In ASME Advances in Design Automation Conference; Proceedings 1995 ASME Advances in Design Automation Conference: Boston, MA, USA, 1995; Volume 82.

12. Carter, C.R.; Rogers, D.S. A framework of sustainable supply chain management: Moving toward new theory. Int. J. Phys. Distrib. Logist. Manag. 2008, 38, 360-387. [CrossRef]

13. Nagurney, A.; Liu, Z.; Woolley, T. Sustainable Supply Chain and Transportation Networks. Int. J. Sustain. Transp. 2007, 1, 29-51. [CrossRef] 
14. Kleindorfer, P.R.; Singhal, K.; van Wassenhove, L.N. Sustainable operations management. Prod. Oper. Manag. 2005, 14, 482-492. [CrossRef]

15. Seuring, S.; Sarkis, J.; Müller, M.; Rao, P. Sustainability and supply chain management-An introduction to the special issue. J. Clean. Prod. 2008, 16, 1545-1551. [CrossRef]

16. United States International Trade Commission. Remanufactured Goods: An Overview of the US and Global Industries, Markets, and Trade; USITC Publication 4356; United States International Trade Commission: Washington, DC, USA, 2012; pp. 332-525.

17. Gutowski, T.G.; Sahni, S.; Boustani, A.; Graves, S.C. Remanufacturing and energy savings. Environ. Sci. Technol. 2011, 45, 4540-4547. [CrossRef] [PubMed]

18. The Business of Reselling Returned Shop Items, The Economist. Available online: http: / / www.economist.com/news/business / 21710855-what-happens-all-goods-shoppers-dont-wantbusiness-reselling-returned-shop-items (accessed on 4 January 2017).

19. Carmona, R.; Fehr, M.; Hinz, J. Optimal Stochastic Control and Carbon Price Formation. SIAM J. Control. Optim. 2009, 48, 2168-2190. [CrossRef]

20. Peters, K. Methodological issues in life cycle assessment for remanufactured products: A critical review of existing studies and an illustrative case study. J. Clean. Prod. 2016, 126, 21-37. [CrossRef]

21. Derigent, W.; Thomas, A. End-of-Life Information Sharing for a Circular Economy: Existing Literature and Research Opportunities. In Computer and Information Science 2010; Springer: Cham, Switzerland, 2016; Volume 640, pp. 41-50.

22. Govindan, K.; Soleimani, H. A review of reverse logistics and closed-loop supply chains: A Journal of Cleaner Production focus. J. Clean. Prod. 2017, 142, 371-384. [CrossRef]

23. Guide, V., Jr.; Daniel, R. Vaidyanathan Jayaraman, and Rajesh Srivastava. Production planning and control for remanufacturing: A state-of-the-art survey. Robot. Comput.-Integr. Manuf. 1999, 15, 221-230. [CrossRef]

24. About ecoATM, Environmental Benefits of ecoATM. Available online: https://www.ecoatm.com/about-us/ (accessed on 16 November 2016).

25. Ayres, R.U.; Ayres, L. (Eds.) A Handbook of Industrial Ecology; Edward Elgar Publishing: Cheltenham, UK, 2002.

26. Fleischmann, M.; Van Nunen, J.A.E.E.; Grave, B. Integrating Closed-Loop Supply Chains and Spare-Parts Management at IBM. Interfaces 2003, 33, 44-56. [CrossRef]

27. Savaskan, R.C.; Bhattacharya, S.; Van Wassenhove, L.N. Closed-Loop Supply Chain Models with Product Remanufacturing. Manag. Sci. 2004, 50, 239-252. [CrossRef]

28. Agrawal, S.; Singh, R.K.; Murtaza, Q. Disposition decisions in reverse logistics: Graph theory and matrix approach. J. Clean. Prod. 2016, 137, 93-104. [CrossRef]

29. Charter, M.; Gray, C. Remanufacturing and product design. Int. J. Prod. Dev. 2008, 6, 375-392. [CrossRef]

30. Subramoniam, R.; Huisingh, D.; Chinnam, R.B. Remanufacturing for the automotive aftermarket-strategic factors: Literature review and future research needs. J. Clean. Prod. 2009, 17, 1163-1174. [CrossRef]

31. Subramoniam, R.; Huisingh, D.; Chinnam, R.B.; Subramoniam, S. Remanufacturing Decision-Making Framework (RDMF): Research validation using the analytical hierarchical process. J. Clean. Prod. 2013, 40, 212-220. [CrossRef]

32. Meng, X. Study of evaluation and selection on third party reverse logistics providers. In Proceedings of the 2008 International Seminar on Business and Information Management, Wuhan, China, 19 December 2008.

33. Efendigil, T.; Önüt, S.; Kongar, E. A holistic approach for selecting a third-party reverse logistics provider in the presence of vagueness. Comput. Ind. Eng. 2008, 54, 269-287. [CrossRef]

34. Prakash, C.; Barua, M. Integration of AHP-TOPSIS method for prioritizing the solutions of reverse logistics adoption to overcome its barriers under fuzzy environment. J. Manuf. Syst. 2015, 37, 599-615. [CrossRef]

35. Alqahtani, A.Y.; Gupta, S.M. Multicriteria Optimization for the Delivery of Products across Multiple Periods in a Reverse Supply Chains Environment. In Applications of Management Science; Emerald Group Publishing Limited: Bingley, UK, 2015; Volume 17, pp. 3-18.

36. Boustani, A.; Sahni, S.; Graves, S.C.; Gutowski, T. Appliance remanufacturing and life cycle energy and economic savings. In Proceedings of the 2010 IEEE International Symposium on Sustainable Systems and Technology, Arlington, VA, USA, 17-19 May 2010.

37. Sutherland, J.; Jenkins, T.; Haapala, K. Development of a cost model and its application in determining optimal size of a diesel engine remanufacturing facility. CIRP Ann. 2010, 59, 49-52. [CrossRef] 
38. Meixell, M.J.; Gargeya, V.B. Global supply chain design: A literature review and critique. Transp. Res. E Logist. Transp. Rev. 2005, 41, 531-550. [CrossRef]

39. Seuring, S.; Müller, M. From a literature review to a conceptual framework for sustainable supply chain management. J. Clean. Prod. 2008, 16, 1699-1710. [CrossRef]

40. Srivastava, S.K. Green supply-chain management: A state-of-the-art literature review. Int. J. Manag. Rev. 2007, 9, 53-80. [CrossRef]

41. Gupta, S.M.; Gungor, A. Issues in environmentally conscious manufacturing and product recovery: A survey. Comput. Ind. Eng. 1999, 36, 811-853.

42. Bellmann, K.; Khare, A. Economic issues in recycling end-of-life vehicles. Technovation 2000, 20, 677-690. [CrossRef]

43. Das, J.K. Responding to Green Concerns: The Roles for Government and Business. Vikalpa 2002, $27,3-12$. [CrossRef]

44. Dekker, R.; Fleischmann, M.; Inderfurth, K.; van Wassenhove, L.N. (Eds.) Reverse Logistics: Quantitative Models for Closed-Loop Supply Chains; Springer Science \& Business Media: New York, NY, USA, 2013.

45. Guide, V., Jr.; Daniel, R. Production planning and control for remanufacturing: Industry practice and research needs. J. Oper. Manag. 2000, 18, 467-483. [CrossRef]

46. Henshaw, J.M. Design for recycling: New paradigm or just the latest'design-for-X'fad? Int. J. Mater. Prod. Technol. 1994, 9, 125-138.

47. Pachauri, R.K.; Allen, M.R.; Barros, V.R.; Broome, J.; Cramer, W.; Christ, R.; Church, J.A.; Clarke, L.; Dahe, Q.; Dasgupta, P.; et al. Climate Change 2014: Synthesis Report. Contribution of Working Groups I, II and III to the Fifth Assessment Report of the Intergovernmental Panel on Climate Change; IPCC: Geneva, Switzerland, 2014.

48. Schipper, M. Energy-related carbon dioxide emissions in US manufacturing. Energy Inf. Adm. 2006, DOE/EIA-0573, 8-10.

49. Fatimah, Y.A.; Biswas, W.K. Remanufacturing as a means for achieving low-carbon SMEs in Indonesia. Clean Technol. Environ. 2016, 18, 2363-2379. [CrossRef]

50. Hammond, R.; Amezquita, T.; Bras, B. Issues in the automotive parts remanufacturing industry: A discussion of results from surveys performed among remanufacturers. Eng. Des. Autom. 1998, 4, 27-46.

51. Corporate Social Responsibility Report. Environment. Available online: https://www.daikin.com/csr/ report/2015web/environment_e.pdf (accessed on 25 April 2016).

52. Dotoli, M.; Meloni, C.; Zhou, M.C. A multi-level approach for network design of integrated supply chains. Int. J. Prod. Res. 2005, 43, 4267-4287. [CrossRef]

53. Guillén-Gosálbez, G.; Grossmann, I.E.; Guillen-Gosálbez, G.; Guillén-Gosálbez, G. Optimal design and planning of sustainable chemical supply chains under uncertainty. AIChE J. 2009, 55, 99-121. [CrossRef]

54. Hugo, A.; Pistikopoulos, E. Environmentally conscious long-range planning and design of supply chain networks. J. Clean. Prod. 2005, 13, 1471-1491. [CrossRef]

55. Hugo, A.; Rutter, P.; Pistikopoulos, S.; Amorelli, A.; Zoia, G. Hydrogen infrastructure strategic planning using multi-objective optimization. Int. J. Hydrogen Energy 2005, 30, 1523-1534. [CrossRef]

56. Jayaraman, V. Production planning for closed-loop supply chains with product recovery and reuse: An analytical approach. Int. J. Prod. Res. 2006, 44, 981-998. [CrossRef]

57. Sheu, J.-B. Green supply chain management, reverse logistics and nuclear power generation. Transp. Res. E Logist. Transp. Rev. 2008, 44, 19-46. [CrossRef]

58. Chaabane, A.; Ramudhin, A.; Paquet, M. Design of sustainable supply chains under the emission trading scheme. Int. J. Prod. Econ. 2012, 135, 37-49. [CrossRef]

59. Paksoy, T.; Bektaş, T.; Özceylan, E. Operational and environmental performance measures in a multi-product closed-loop supply chain. Transp. Res. E Logist. Transp. Rev. 2011, 47, 532-546. [CrossRef]

60. Abdallah, T.; Farhat, A.; Diabat, A.; Kennedy, S. Green supply chains with carbon trading and environmental sourcing: Formulation and life cycle assessment. Appl. Math. Model. 2012, 36, 4271-4285. [CrossRef]

61. Bhinge, R.; Moser, R.; Moser, E.; Lanza, G.; Dornfeld, D. Sustainability Optimization for Global Supply Chain Decision-making. Procedia CIRP 2015, 26, 323-328. [CrossRef]

62. Diabat, A.; Simchi-Levi, D. A carbon-capped supply chain network problem. In Proceedings of the 2009 IEEE International Conference on Industrial Engineering and Engineering Management, Hong Kong, China, 8-11 December 2009. 
63. Alkhayyal, B.; Eckelman, M.J.; Gupta, S.M. Managing transportation of products and greenhouse gas emissions in reverse supply chains. In Proceedings of the 27th Production and Operations Management Society (POMS) Annual Conference, Orlando, FL, USA, 6-9 May 2016.

64. Abdallah, T.; Al-Refaie, A.; Diabat, A.; Svetinovic, D.; Govindan, K. Strategic Closed-Loop Facility Location Problem with Carbon Market Trading. IEEE Trans. Eng. Manag. 2013, 60, 398-408.

65. Fahimnia, B.; Sarkis, J.; Dehghanian, F.; Banihashemi, N.; Rahman, S. The impact of carbon pricing on a closed-loop supply chain: An Australian case study. J. Clean. Prod. 2013, 59, 210-225. [CrossRef]

66. Benjaafar, S.; Li, Y.; Daskin, M. Carbon Footprint and the Management of Supply Chains: Insights From Simple Models. IEEE Trans. Autom. Sci. Eng. 2013, 10, 99-116. [CrossRef]

67. Jin, M.; Granda-Marulanda, N.A.; Down, I. The impact of carbon policies on supply chain design and logistics of a major retailer. J. Clean. Prod. 2014, 85, 453-461. [CrossRef]

68. Wang, Y.; Chen, W.; Liu, B. Manufacturing/remanufacturing decisions for a capital-constrained manufacturer considering carbon emission cap and trade. J. Clean. Prod. 2017, 140, 1118-1128. [CrossRef]

69. Dornfeld, D.A. Moving towards green and sustainable manufacturing. Int. J. Precis. Eng. Manuf. Technol. 2014, 1, 63-66. [CrossRef]

70. Nagurney, A.; Liu, Z.; Woolley, T. Optimal endogenous carbon taxes for electric power supply chains with power plants. Math. Comput. Model. 2006, 44, 899-916. [CrossRef]

71. Subramanian, R.; Talbot, B.; Gupta, S. An Approach to Integrating Environmental Considerations Within Managerial Decision-Making. J. Ind. Ecol. 2010, 14, 378-398. [CrossRef]

72. Biswas, W.K.; Duong, V.; Islam, M.N.; Frey, P. A comparison of repaired, remanufactured and new compressors used in Western Australian small- and medium-sized enterprises in terms of global warming. J. Remanuf. 2013, 3, 4. [CrossRef]

73. Zanghelini, G.M.; Cherubini, E.; Orsi, P.; Soares, S.R. Waste management Life Cycle Assessment: The case of a reciprocating air compressor in Brazil. J. Clean. Prod. 2014, 70, 164-174. [CrossRef]

74. Latham, G. Vehicle Remanufacturing: Economic and Environmental Expansion of the Life Cycle; No. 2016-01-1291. SAE Technical Paper; SAE 2016 World Congress and Exhibition: Detroit, MI, USA, 2016.

75. Zhou, X.; Schoenung, J. Application of environmental accounting information to the decision-making for the environmentally conscious design and end-of-life management of cellular phones. In Proceedings of the 2006 IEEE International Symposium on Electronics and the Environment, Scottsdale, AZ, USA, 8-11 May 2006.

76. Mihelcic, J.R.; Crittenden, J.C.; Small, M.J.; Shonnard, D.R.; Hokanson, D.R.; Zhang, Q.; Chen, H.; Sorby, S.A.; James, V.U.; Sutherland, J.W.; et al. Sustainability Science and Engineering: The Emergence of a New Metadiscipline. Environ. Sci. Technol. 2003, 37, 5314-5324. [CrossRef]

77. Interagency Working Group. Technical Update on the Social Cost of Carbon for Regulatory Impact Analysis-Under Executive Order 12866; Interagency Working Group on Social Cost of Carbon, United States Government: Washington, DC, USA, 2013.

78. US Environmental Protection Agency, The Social Cost of Carbon. Climate Change-Social Cost of $\mathrm{CO}_{2}$, 2015-2050. Available online: http://www3.epa.gov/climatechange/EPAactivities/economics/scc.html (accessed on 14 November 2015).

79. United States Energy Information Agency (EIA). U.S. Manufacturing Energy Consumption Survey (MECS); United States Energy Information Agency (EIA): Dubuque, IA, USA, 2010.

80. United States Energy Information Agency (EIA). U.S. Commercial Buildings Energy Consumption Survey (CBECS); United States Energy Information Agency (EIA): Dubuque, IA, USA, 2012.

81. Consumer Price Index, US Department of Labor. Available online: www.bls.gov/news.release/cpi.toc.htm (accessed on 15 April 2016).

82. Carnegie Mellon University Green Design Institute, Economic Input-Output Life Cycle Assessment (EIO-LCA) US 2002 (428 Sectors) Producer Model. Available online: http:/ / www.eiolca.net/ (accessed on 19 April 2016).

83. Pochampally, K.; Nukala, S.; Gupta, S. Strategic Planning Models for Reverse and Closed-Loop Supply Chains; CRC Press: Boca Raton, FL, USA, 2008.

84. Gupta, S.M. Reverse Supply Chains: Issues and Analysis; CRC Press: Boca Raton, FL, USA, 2016.

85. U.S. Energy Information Administration. Table 5.6.A. Average Price of Electricity to Ultimate Customers by End-Use Sector, Electric Power Monthly. Available online: http:/ / www.eia.gov/electricity/monthly/epm table_grapher.cfm?t=epmt_5_6_a (accessed on 20 January 2016). 
86. LG Electronics. Air Conditioners, LG Model: LW1213ER. Available online: http://www.lg.com/us/airconditioners/lg-LW1213ER-window-air-conditioner (accessed on 17 November 2016).

87. World Wide Voltage, LG Electronics. Air Conditioners, LG Model: LW1213ER Refurbished. Available online: http:/ / www.worldwidevoltage.com/lg-lw1213er-12-000-btu-window-air-conditioner-with-remotefectory-refurbished--only-for-usa--.html?utm_source=googlepeplaandutm_medium=adwordsandid= 61865531738 (accessed on 17 November 2015).

88. Penske Truck Leasing Corporation. 12 Foot Truck. Available online: http://www.pensketruckrental.com/ moving-trucks/12-foot-truck/ (accessed on 23 November 2015).

89. Moore, F.C.; Diaz, D.B. Temperature impacts on economic growth warrant stringent mitigation policy. Nat. Clim. Chang. 2015, 5, 127-131. [CrossRef]

(C) 2019 by the author. Licensee MDPI, Basel, Switzerland. This article is an open access article distributed under the terms and conditions of the Creative Commons Attribution (CC BY) license (http:/ / creativecommons.org/licenses/by/4.0/). 